
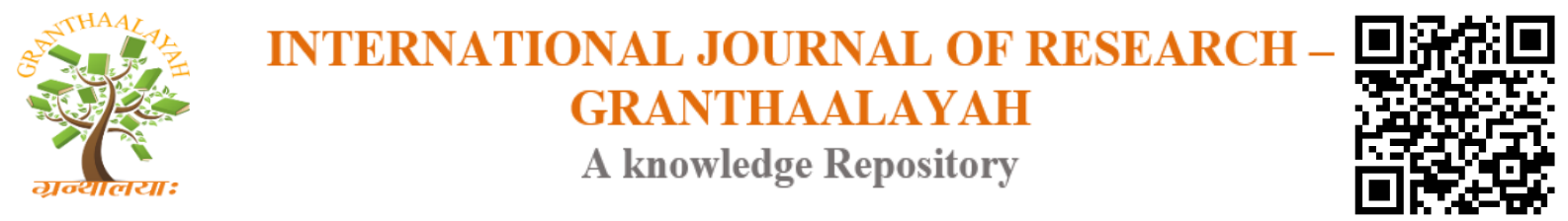

Management

\title{
ALUMNI FROM THE INSTITUTO FEDERAL FLUMINENSE, BOM JESUS DO ITABAPOANA CAMPUS: AN ANALYSIS OF THEIR ENTRY INTO THE WORLD OF WORK
}

\author{
Eliane Amélia Valinho Abreu ${ }^{1}$, Ludmila Gonçalves da Matta ${ }^{2}$ \\ ${ }^{1}$ Master in Regional Planning and City Management -Universidade Candido Mendes/Campos \\ dos Goytacazes, state of Rio de Janeiro, Brazil \\ ${ }^{2} \mathrm{PhD}$ in Political Sociology - Professor at the Masters and Doctorate Program in Regional \\ Planning and City Management at the Universidade Candido Mendes/Campos dos Goytacazes, \\ state of Rio de Janeiro, Brazil
}

\begin{abstract}
Studies on alumni are of extreme relevance insofar as they enable a survey of information that can generate results relating to the planning, definition, and feedback of educational policies. The study sought to analyze the alumni of the technical course in Farming of the Instituto Federal Fluminense, Bom Jesus do Itabapoana campus, and their entry into the world of work. The campus is set in a rural area, where the Local Productive Arrangement is farming. It has to be considered that Law 11,892/2008, which established the Federal Institutes of Education, Science, and Technology, adopts as their purpose/characteristic and goals to provide professional and technological education at all levels and modalities, training and qualifying professionals, focusing on the local and regional socio-economic development; stimulate and support educational processes that lead to the generation of work and income and the emancipation of citizens from the perspective of local and regional socio-economic development. This study included the years 2012, 2014, and 2016. The research is of a quantitative-qualitative aspect due to the importance of complementation among the different methodologies for a better understanding of the subject of study by means of a questionnaire. A documentary and online survey was carried out in order to support and understand the subject addressed. Findings revealed that most alumni continue to study and that there is no significant number of technical alumni in farming working in the field, considering as an incentive the lack of investment in the region; however, the alumni are confident in a perspective of growth in the field.
\end{abstract}

Keywords: Farming; Vocational; Technical Education; Alumni Career Tracking.

Cite This Article: Eliane Amélia Valinho Abreu, and Ludmila Gonçalves da Matta. (2020). "ALUMNI FROM THE INSTITUTO FEDERAL FLUMINENSE, BOM JESUS DO ITABAPOANA CAMPUS: AN ANALYSIS OF THEIR ENTRY INTO THE WORLD OF WORK." International Journal of Research - Granthaalayah, 8(4), 216-229. https://doi.org/10.29121/granthaalayah.v8.i4.2020.27. 


\section{Introduction}

Alumni of educational institutions prove to be potential actors who promote interaction with society, a source of information that makes it possible to depict how society, in general, understands and evaluates the institutions, both from the point of view of the educational process and the level of interaction they achieve. As such, it is essential that educational institutions establish a communication channel with this group.

Researches about alumni are important in this context, insofar as it enables the gathering of information regarding the situation of alumni in the world of work. These findings are essential for the planning, definition, and feedback of educational policies of institutions (BRASIL, 2008).

One of the difficulties in institutional evaluations may be the limited information available, as students have already left the institution, monitoring them becomes more complex. Hence, it is necessary to create demands in the routine of completing and updating student data throughout the course, in order to enable him/her perception regarding the course, as well as the level of commitment of the institution to society.

As such, this research has a special relevance considering that federal institutes have as their characteristic and goal the provision of professional and technological education, providing the qualification of citizens for professional performance, in accordance with the development and local and regional economy.

As Lousada and Martins (2005) state, educational institutions are responsible for implementing the evaluation procedure that best meets their characteristics and expectations. Hence, the institutional evaluation definitely assists them to rethink their administrative, technical, and pedagogical practices in a critical and committed manner, pondering their role in society as promoters of knowledge for understanding and changing reality.

The development of full social subjects, together with the goals of education in its social, political, and pedagogical meaning of training for citizenship, should not be limited to the immediate needs of professional qualification imposed by the labor market, as well as to the fact that it cannot disregard it.It is clear, then, that the discussion on work and education is vital for understanding the profile of the worker in the current scenario.

The Brazilian educational system has been characterized by a history of exclusion and dualism in which the access to education is directly related to the political and economic interests of the country in each period. In this way, the educational trajectory is seen as an element of reorientation of the population in line with the intended direction by society from a political ideal (SHANCHES, 2012).

The training of man in capitalist production plays an important role in understanding social relations and their transformations, taking into account that industrial work has become more complex, and the qualification has achieved sociological relevance. 
According to Ramos (2006, p. 26),

The human being produces his/her existence by means of work and, by this means, interacts with nature and with other people, developing economic and social relations. In this way, analyzing the forms, processes, and perspectives that human formation assumes in capitalist society implies investigating the multiple forms that collective work takes, and the way the person acts and modifies oneself by shaping oneself in part of that work. (free translation)

Training for work from an integral and unitary perspective, which has the work as an educational principle, comprises the learning of technical skills; however, its main focus is on students perceiving the scientific data as the basis of various technologies, which distinguish the relations of production and their production processes, as well as the technologies and technological knowledge on which the different techniques of production are based. (MARON; GERMAN, 2010).

Because of changes in the world of work resulting from new forms of organization and management, the traditional forms of professional education, based on the Taylorist/Fordist paradigm, are becoming historically outdated. (KUENZER, 2000).

From this perspective, training at the technical level is a link between the man of science and the worker, acting as an intermediary employee within the capitalist company. Most of the industrial technicians perform the functions of coordination and supervision. (MACHADO, 1989).

As education is aware of the transformations that occur in the capitalist way of production and more likely to adapt to the demands of the market, there is a tendency for models and pedagogical proposals to follow the evolution of technologies and the new forms of organizing production.

This scenario leads to some considerations developed hereafter.

Vocational and Technical Education (ETP, in Portuguese) focuses on developing more practical skills that are directly related to a specific occupation (or group of occupations). In turn, regular education develops skills in a wider range of subjects in a conceptual and abstract way.

On December 29, 2008, with the enactment of Law No. 11,892/2008, 31 Federal Centers of Technological Education (CEFETs, in Portuguese), 75 Off-Campus Education Units(UNEDs, in Portuguese), 39 Agro-technical Schools (EAFs in Portuguese), seven Federal Technical Schools (ETFs, in Portuguese), and eight Associated Technical Schools (ETVs, in Portuguese) to universities, were discontinued to establish the Federal Institutes of Education, Science, and Technology.The Federal Institutes emerged from the transformation or grouping of existing institutions that chose to change and, because of this, have a different structure (BRASIL, 2008). Vocational and technological education becomes a strategic value for national development, consistent with regional and local development, resulting from the transformations over the past decades in the Federal Education System.

In accordance with the law establishing Federal Institutes (Law No. 892/2008), these institutions now comprise Rectors' offices, and the highest manager of each Federal Institute must be a Rector.Hence, each Rectors' offices has its own campuses, run by managers who must be named 
General Directors. These institutions aim at articulating with the territory where they are inserted, with a view to contributing to local and regional development. (BRASIL, 2008).

As for high school, the reform proposed in 2013, which suggested establishing full time, organizing curricula by fields of knowledge, and amending some articles of the Education Guidelines and Bases Law No. 9,394/1996 (LDB in Portuguese), was consolidated in 2017 by Law No. 13,415, in a scenario composed of very different opinions. (BRASIL, 2017).

The interest in studying the alumni of the technical course in Farming is because it is located on a mainly rural campus, which Local Productive Arrangement (APL in Portuguese) is farming and its developments. Hence, this study intends to profile the alumni from the technical course in Farming of the Instituto Federal Fluminense Campus Bom Jesus do Itabapoana and to analyze how they are introduced in the work area, while observing whether the institution has fulfilled its role of training critical and thoughtful individuals.

This is a quantitative and qualitative exploratory-descriptive research, carried out using a case study, comprising documentary research and data collection from 72 students in the last years of the technical course in agriculture, in the integrated and concomitant modalities, of the years 2012, 2014, and 2016, between January and February 2019.

The vocational education field includes a set of conflicts pervaded by an uncritical approach, which deals with the relationship among education, vocational training, and development linearly, without considering the dualism in the educational field and the power structure in the social relations that generate and naturalize the asymmetrical relations between countries in the central, peripheral, and semi-peripheral zones of capitalist societies.

On the basis of the considerations presented in this study, the following questions arise: what vocational education is being offered in Brazil? In what context is it consolidated? What is the relationship between vocational training and the labor market?

\section{Materials and Methods}

This study was conducted by a descriptive, exploratory research, which aims at clarifying different issues. It was developed to provide a better understanding of the subject under investigation, to make it more clearly understood, and to construct an overview of a certain fact or situation, encompassing bibliographic surveys and research to help understand it (GIL, 2010).

Gil (2010, p. 44) says that a descriptive research is helpful in finding and describing characteristics of a particular population, with "numerous studies that can be classified under this theme and one of their most significant characteristics is the use of standardized data collection techniques."

Exploratory research is employed when the researcher encounters few studied themes, which leads to difficulties in formulating hypotheses, generally assuming the forms of Bibliographical Research and Case Studies (GIL, 2010). 
A case study, as Yin (2015, p. 32) states, is "an empirical investigation, which examines a contemporary phenomenon within its real life context, especially when the boundaries between the phenomenon and the context are not clearly defined."

To develop the study, a survey was conducted with the alumni of the Instituto Federal Fluminense (IFFluminense in Portuguese), campus Bom Jesus, of the years 2012, 2014, and 2016.Based on data from the Coordination of Academic Records of that institution, 161 technicians were graduated in the corresponding years, 121 in the integrated education and 40 in the concomitant education.

The campus of Bom Jesus do Itabapoana is located in the countryside of the Northwest of Rio de Janeiro state, with an agricultural structure and a reputation obtained due to some factors, such as the demand for enrollments from the years 1970 to today, resulting in a strengthening of the ETP.Its history started much prior to the institutionalization of the Instituto Federal de Educação, Ciência e Tecnologia, and it has always had a very strong presence in this municipality. Hence, to understand the way this role has been represented in society with respect to the labor market, the continuity of studies and whether the institution has fulfilled its purpose as defined in its law of establishment has become the focus of this study.

Thiscampus is located in the Northwest of the state of Rio de Janeiro, which intersects with the South of the states of Espírito Santo and Minas Gerais, an eminently agricultural region that lacks the most advanced techniques and technologies that guarantee an increase in productivity and an improvement in the quality of the products to be offered, with quality for the packaging, storage, distribution, and commercialization of farming production. (IFFLUMINENSE, 2012).

The integrated Farming technical course lasts three years, and the concomitant one, two years, offered in the morning and afternoon shifts, with the goal of training the student for the labor market. The access to the course takes place by means of a selection process of equal opportunities for access and remaining at the Institution. It is an annual process, which adopts the provisions set forth in the regulations organized by the committee responsible for the selection process for admission, in accordance with the Federal Constitution, the LDB, Opinion No. 95/1998, Decrees No. 5,224/2004 and 5,773/2006, and Law No. 11,892/2008, which created the Federal Institutes of Education, Science and Technology. (IFFLUMINENSE, 2016).

In accordance with the Pedagogical Course Plan (PPC in Portuguese) of the technical course in Farming, the IFF campus Bom Jesus do Itabapoana has the task of enabling human resources to plan, produce, evaluate, analyze, and apply knowledge and information related to plant and animal production; providing educational subsidies so that the technician can think and execute, in an attempt to promote the development of production areas, observing market trends and current legislation; promoting diversity of training allowing greater employability; and competing for regional development. (IFFLUMINENSE, 2016).

In line with the IFFluminense Campus Bom Jesus do Itabapoana (2016) website, the Farming technician graduated by the Institution is a professional qualified to work at any stage of the farming production chain, either in the supply of productive resources - sale of inputs, sale of 
machinery and equipment, provision of services, rural credit - or in the agricultural/zootechnical production itself, or in the commercialization of the related products.

This survey was conducted during the months of January and February 2019 via phone contacts, social networking (Facebook), instant messaging application (WhatsApp), and online forms services platform (Google Forms). Seventy-two former students completed a survey, which took an average of eight minutes to fill out.

\section{Results and Discussions}

The quantitative analysis of the survey data required the use of statistical techniques with results gathered from information taken from the questionnaire conducted by Google Forms platform and document analysis. The stratification was made using the results obtained from students of the integrated and concomitant modalities. It should be mentioned that, in this study, students who effectively concluded the regular studies, internships, and other activities foreseen in the Pedagogical Course Plan, and who were able to receive a diploma or had already received it, were considered as alumni.

The thematic analysis was chosen for the qualitative analysis of the data, for what Bardin (2011) calls 'meaning nuclei'. For this purpose, the following thematic units were created in the questionnaire: general information; analysis of the current professional situation; evaluation of the course/institution; and self-evaluation of the alumnus. At the end, the participants were asked to make a comment or a suggestion that could contribute to their better insertion in the labor market.

\section{General Information}

The first thematic unit attempted to verify general information from the sample. The data collected are depicted in Table 1.

Table 1: General sample information

\begin{tabular}{|l|c|}
\hline Variable & $\%$ \\
\hline Gender & 47.2 \\
\hline Female & 52.8 \\
\hline Male & 72.2 \\
\hline Age at completion of course \\
\hline Up to 18 years old & 27.8 \\
\hline Between 19 and 23 years old & \\
\hline Course modality & 80.6 \\
\hline Integrated & 19.4 \\
\hline Concomitant & 80.6 \\
\hline Student source & 8.3 \\
\hline Public school & 11.1 \\
\hline Private school \\
\hline Private and public school \\
\hline Current level of education \\
\hline Stopped studying & 43.1 \\
\hline Under graduation & 47.2 \\
\hline
\end{tabular}




\begin{tabular}{|l|l|}
\hline Specialization & 6.9 \\
\hline Master's degree & 2.8 \\
\hline
\end{tabular}

Source: Data collected by the author

A balance was observed regarding male $(52.8 \%)$ and female $(47.2 \%)$ alumni, with a small benefit for the female ones, in which $72.2 \%$ of the students graduated at the age of up to 18 years old, while $27.8 \%$ of those who completed the course had age from 19 to 23 years old. As for the modality of the course, a predominance $(80.6 \%)$ was observed in the integrated modality, while $19.4 \%$ attended the course concomitantly.

It should be stressed that the greatest number of graduate students in regular age (18 years old) results from a higher percentage of students in the integrated modality, and the concomitant modality offers a smaller number of places. The concomitant modality of the technical course enables the admission of students who have not had the opportunity to enroll in the regular age, due to different issues, or who have not managed to get a place in the integrated modality.

A significant percentage $(80.6 \%)$ of the sample comes from public schools, $8.3 \%$ come from private institutions, and $11.1 \%$ have attended public and private schools. Despite the fact that, in the period analyzed, there was still no implementation of the legislation on equity shares, the institution had already a significant number of public school students. It should be noted that the places available in the selection processes are disputed, with an average of three candidates per place in the courses offered by the institution, demonstrating the importance of the public school system and the commitment of students to obtain them.

In relation to the current level of education, a percentage of $43.1 \%$ of the sample did not continue their studies; on the other hand, most of them reached graduation (47.2\%), specialization (6.9\%), and master's $(2.8 \%)$.In this context, it appears that the alumni that have continued or are still studying prove that the student has sought to reach a higher education level. Moreover, the level of education can contribute to reducing social inequalities and provide a universe of opportunities in the world of work.

\section{Analysis of the Current Professional Situation}

In this unit, the goal was to investigate whether the alumnus is in the world of work or is focusing on continuing education, as well as his/her degree of personal satisfaction, and his/her expectations for professional and social growth. The results of the professional situation of the sample are displayed in Table 2.

Table 2: Analysis of the professional situation

\begin{tabular}{|l|c|}
\hline Variable & $\%$ \\
\hline Current professional situation & 47.9 \\
\hline Studying & 25.4 \\
\hline Working and studying & 21.1 \\
\hline Working & 5.6 \\
\hline Neither working nor studying & \\
\hline Working in the field of training & 30.4 \\
\hline Yes & \\
\hline
\end{tabular}




\begin{tabular}{|l|c|}
\hline No, he/she works in areas other than his/her area of study & 69.6 \\
\hline \multicolumn{2}{|l|}{ Reason for not working in the field of training } \\
\hline Private reasons & 28.9 \\
\hline Lack of opportunities & 29.1 \\
\hline Better opportunities in other fields & 18.5 \\
\hline Other reasons & 23.5 \\
\hline Time taken to enter the labor market & 45.6 \\
\hline Less than 1 year & 21.1 \\
\hline Between 1 and 2 years & 7 \\
\hline Between 2 and 3 years & 10.5 \\
\hline Between 3 and 4 years & \\
\hline Employment relationship & 18.2 \\
\hline Signed employment record & 12.1 \\
\hline Informal job & 1.5 \\
\hline Public tender (statutory) & 12.1 \\
\hline Temporary contract & 9.1 \\
\hline Self-employed & 47 \\
\hline No employment relationship & \\
\hline Means of obtaining the job & 60.9 \\
\hline Not applicable to the current situation & 20.3 \\
\hline Recommendation by influential people & 9.4 \\
\hline Resume selection & 4.7 \\
\hline Public tender and/orpost-internship hiring & 83.3 \\
\hline Monthly income & 16.7 \\
\hline Up to 2 minimum wages & \\
\hline Between 2 and 5 minimum wages & \\
\hline
\end{tabular}

Source: Data collected by the author

When the current professional situation was verified, it was seen that $47.9 \%$ are only studying, $25.4 \%$ are working and studying, $21.1 \%$ are only working, and $5.6 \%$ are neither working nor studying. It should be mentioned that the Bom Jesus campus offers a higher education in Food Science and Technology, with enrollments of the alumni that participated in this research.

Regarding the total number of alumni, 30.4\% are working in their area of education, while $69.6 \%$ said they work in different areas. When asked why they do not work within their area of education, $29.1 \%$ stated that they are not working due to lack of opportunities; $28.9 \%$, for particular reasons; $18.5 \%$ because of better opportunities in another area; and $23.5 \%$, for other reasons.

The alumni reported that the Northwest region of the state of Rio Grande do Sul (NWR) does not have much job opportunities, which leads to a lack of interest by students in pursuing their careers. Hence, municipal, state, and federal governments need to create strategies to promote farming, since it is the principal source of income in the region. 
Among the ones who are already in the labor market, when asked about the time they took to enter the market, $45.6 \%$ reported it was in less than one year; $21.1 \%$, between one and two years; $7 \%$, between two and three years; $10.5 \%$, between three and four years; and $15.8 \%$ in over four years.

With respect to employment, $18.2 \%$ work with a signed labor card; $12.1 \%$ work without a signed labor card, revealing an informality; $1.5 \%$ work with a public tender; $12.1 \%$ work with a temporary contract; and $9.1 \%$ are able to work as self-employed. The percentage of alumni without employment reaches $47 \%$.

In response to questions about how they were employed today, $60.9 \%$ responded the question did not apply to the current situation; $20.3 \%$ were indicated by influential people; $9.4 \%$, by resume; and $4.7 \%$, by public tender and post-internship hiring. Such data show the importance and the need for the Institution to establish programs intended for the entry of the alumni into the world of work. In relation to income, $83.3 \%$ of workers earn up to two minimum wages per month, while $16.7 \%$, between two and five minimum wages.

As mentioned above, a large percentage of alumni are not working, but studying, which may indicate a choice for higher education, rather than entering the world of work as a technician. It must also consider that the municipality has a reduced Gross Domestic Product (GDP), with its economy characterized by informality in relation to activity and lack of investment in farming modernization, which results in a salary range around two minimum wages (CEPERJ, 2018).

The data on satisfaction and professional growth perspectives are depicted in Table 3.

Table 3: Job satisfaction and professional growth expectations

\begin{tabular}{|l|c|}
\hline Variable & \% \\
\hline \multicolumn{2}{|l|}{ Degree of satisfaction with his/her professional activity } \\
\hline Very satisfied & 26.7 \\
\hline Satisfied & 46.7 \\
\hline Dissatisfied & 13.3 \\
\hline Indifferent & 13.3 \\
\hline Degree of satisfaction regarding the salary issue \\
\hline Satisfied & 24.6 \\
\hline Very satisfied & 14 \\
\hline Dissatisfied & 26.3 \\
\hline Very Dissatisfied & 12.3 \\
\hline Indifferent & 22.8 \\
\hline Expectations on professional growth \\
\hline Great & 36.2 \\
\hline Good & 31.9 \\
\hline Reasonable & 18.8 \\
\hline
\end{tabular}

Source: Data collected by the author

With regard to the degree of satisfaction with their professional activity, $26.7 \%$ stated that they were very satisfied; $46.7 \%$ considered themselves to be satisfied; $13.3 \%$ expressed dissatisfaction; and $13.3 \%$ expressed indifference. Even though a significant percentage of the group is satisfied 
with their current professional activity, it must be considered that, on the basis of the previous data, most of them are not within their technical area. Consequently, a conclusion could be that the different areas of technical training would be better paid or providing greater personal satisfaction.

A dissatisfaction was noted with regard to wages for alumni entering the world of work, with only $24.6 \%$ satisfied and $14 \%$ very satisfied; while $26.3 \%$ consider themselves dissatisfied, $22.8 \%$ are indifferent, and $12.3 \%$, very dissatisfied. Regarding the social aspect, a great percentage $(40.63 \%)$ of alumni are satisfied. The alumni expressed satisfaction and saw the Institution as an opportunity to contribute to their full and humanistic education. It is important to point out that the Federal Institutes were created with a view to promoting justice, equality, and social inclusion.

Respondents were asked about their professional growth perspectives in their field, and a positive perspective was observed, with $36.2 \%$ for optimum; $31.9 \%$ for good; and $18.8 \%$ considered reasonable. The percentage of agricultural technician working in the area is not the most expressive according to the alumni because they state the Northwest region of the state of Rio de Janeiro does not offer great job opportunities, thus generating a lack of interest by students to make their careers.

\section{Course/Institution Evaluation}

The objective of this unit was to collect information on the education preparation for the world of work, as well as the perception of the relevance of the course and of the vocational subjects, and the qualification of teachers for their education and technical-scientific and cultural development. This can be seen in Table 4.

Table 4: Course/Institution evaluation

\begin{tabular}{|l|c|}
\hline Variable & $\%$ \\
\hline Preparation for the world of work & 30.6 \\
\hline Very prepared & 52.8 \\
\hline Reasonably & 16.6 \\
\hline Little or not prepared & 43.1 \\
\hline Contribution of vocational subjects to professional performance \\
\hline Great & 29.2 \\
\hline Reasonable & 3.1 \\
\hline Little or any & 29.2 \\
\hline Does not apply to the current occupation & 86.1 \\
\hline Contribution of the course to cultural/personal development \\
\hline Great & 12.5 \\
\hline Reasonable & 1.4 \\
\hline Little or nothing & 70.8 \\
\hline Contact with the institution after graduation & 12.5 \\
\hline No & 11.1 \\
\hline Research for information & \\
\hline Participation in events of the Institution & \\
\hline
\end{tabular}

Source: Data collected by the author

In an evaluation of the course and of the Institution within the sample, it could be seen that the technical course in Agriculture of the IFF Bom Jesus shows some integration with the world of 
work, considering that $30.6 \%$ of the egresses believe themselves to be very prepared; $52.8 \%$ feel reasonably prepared; and only $16.6 \%$ consider themselves little or not prepared for the labor market. It should be stressed that the destination of the alumnus shall not be only to the campus of his/her education, but to the region as a whole, as well as to the country.

A percentage of $43.1 \%$ believes that vocational subjects contributed to their professional performance; after $29.2 \%$, who find this contribution reasonable; $23.6 \%$, who consider that the question does not apply to current work; and 3.1\%, who think that they contributed little or nothing. It should be specified that the course has a curriculum grid with a significant course load of practical classes.

In accordance with the curriculum grid of the technical course in Farming, concomitant modality, the students have 200 hours of propaedeutic subjects, 1400 hours of specific subjects, totaling a course load of 1600 hours. In the integrated modality, it offers 2400 hours of propaedeutic subjects and 1400 hours of specific subjects, totaling 3800 hours (IFF, 2016).

When asked if the course helped to their cultural/personal development, $86.1 \%$ reported that it contributed a lot; $12.5 \%$, reasonably contributed; and $1.4 \%$ considered it contributed little or nothing. It should be noted that most of the alumni are in agreement with the contribution of this institution to their development. The alumni believe that the teachers are well educated, most of them having a post-graduation at a doctorate degree, and their continuing education is constantly stimulated by the Institution. This result is justified as a reflection of the institution policy towards valuing teachers. The IFF fosters the valorization of professionals by means of qualification.

Most of the alumni (70.8\%) have not kept in touch with the IFF Bom Jesus. Yet, $12.5 \%$ have sought information, while $11.1 \%$ participate in the events organized by the institution, such as "Indigenous April", " Knowledge Exhibition: teaching, research, and extension", "Black November", among others.

The alumni assigned a good concept and a great concept to the technical course in Farming, which proves the relevance in investigating the course. When asked about the reason for choosing the course, the questions regarding affinity and quality of teaching are highlighted, showing the importance of federal schools and the technical course in Farming.

\section{Self-Evaluation of Alumni}

The last theme analysis of the questionnaire focused on the self-evaluation carried out by the alumni. The results can be verified in Table 5.

After being asked about the commitment to the studies in the technical course in Farming, 33.3\% evaluated it was great; $45.8 \%$ considered it good; and 20.8 evaluated it as regular. These observations are significant because they allow students to be able to make a more critical analysis of the course.

Analyzing their punctuality and attendance to classes, $45.8 \%$ considered it great; $40.3 \%$ said it was good; and 13.9 evaluated it as regular or bad. These results support the commitment of the alumni to the course, the importance of the education provided by the federal technical schools, and the 
interest of the students in a high-quality study that provides them with more advantageous conditions in society.

As for the student participation in academic and cultural activities organized by the IFF during the course, $43.1 \%$ considered that their participation was great; $45.8 \%$ thought it was good; and $11.1 \%$ evaluated it was regular. It is worth mentioning that the Institution fosters the participation of students in activities that contribute to their learning, taking into account that they go beyond conventional classes, stimulating interest and socio-cultural growth.

Table 5: Self-evaluation of alumni

\begin{tabular}{|l|c|}
\hline Variable & $\%$ \\
\hline Commitment to study & 33.3 \\
\hline Great & 45.8 \\
\hline Good & 20.8 \\
\hline Regular \\
\hline Punctuality and attendance \\
\hline Great & 45.8 \\
\hline Good & 40.3 \\
\hline Regular & 13.9 \\
\hline Participation in academic and cultural activities \\
\hline Great & 43.1 \\
\hline Good & 45.8 \\
\hline Regular & 11.1 \\
\hline Self-evaluation as a student & 31.9 \\
\hline Great & 56.9 \\
\hline Good & 11.1 \\
\hline Regular
\end{tabular}

Source: Data collected by the author

By making a self-evaluation on how they were as students, $31.9 \%$ of the students considered themselves great; $56.9 \%$ were good; and $11.1 \%$ regarded themselves as regular, which was considered a positive result for the institution and for the alumni.

\section{Conclusions}

This study aimed at analyzing how the alumni of the technical course in Farming of IFF luminense - Campus Bom Jesus do Itabapoana, in the integrated and concomitant modalities, in 2012, 2014, and 2016, have been included in the world of work and how the Institution contributed in this respect and in its formation, and whether they continued their studies. The alumni may be regarded as an important point for research, given that it is an indicator of information that expresses the institutional educational process in society.

The study of the alumni can consider various aspects concerning the functioning of the Institution: as to the professional education provided by the campus; whether or not the continuity of studies is expected to be successful; and as to the professional practice. 
It is important to emphasize that the farming activity plays a significant role in the economy of the region, thereby meeting the requirements of Law No. 892/2008, which deals with the establishment of Federal Institutes. Moreover, one of the purposes and characteristics of such law is the adaptation of technical solutions as an educational process, to meet the regional characteristics.

Based on the results achieved, the indicators referring to the continuity of studies show that the highest percentage of alumni aims at the continuity of studies, including undergraduate, specialization and master's degrees. The indicators also suggest that, regarding the insertion in the world of work, there is an absorption considered slight related to the performance in the area of education, with a percentage of only $13 \%$ working in the area.

In general, the alumni considered the course as good and point to a perspective of growth, although seeking other degrees of study. Such fact can be considered given the difficulty of opportunities in some municipalities or territories and the lack of investment by the government.

It should be emphasized that the data of this survey with alumni of the IFF Campus Bom Jesus do Itabapoana were conducted only in one technical course among the many existing in the country, with the need to develop broader research on the course of Farming and the world of work.

A limiting factor in the study was that there was no up-to-date data record, which made it difficult to contact the alumni, since they moved home and telephone numbers, but did not share this information with the Coordination of Academic Records.

\section{References}

[1] BARDIN, L. Análise de conteúdo. São Paulo: Edições 70, 2011.

[2] BRASIL. Lei $\mathrm{n}^{\circ} 11.892$, de 29 de dezembro de 2008. Institui a Rede Federal de Educação Profissional, Científica e Tecnológica, cria os Institutos Federais de Educação, Ciência e Tecnologia, e dá outras providências. Brasília: Senado Federal, 2008.

[3] Lei n ${ }^{\circ} 13.415$, de 13 de fevereiro de 2017. Lei de Diretrizes e Bases da Educação Nacional. Brasília: Senado Federal, 2017.

[4] Lei ${ }^{\circ}$ 9.394, de 20 de dezembro de 1996. Lei de Diretrizes e Bases da Educação Nacional. Estabelece as diretrizes e bases da educação nacional. Brasília: Senado Federal, 1996.

[5] CEPERJ. Fundação Centro Estadual de Estatísticas, Pesquisas e Formação de Servidores Públicos do Rio de Janeiro. Estatísticas: Bom Jesus do Itabapoana. 2018. Disponível em: http://www.ceperj.rj.gov.br/. Acesso em: 14 maio 2019.

[6] GIL, A. C. Como elaborar projetos de pesquisa. 5. ed. São Paulo: Atlas, 2010.

[7] INSTITUTO FEDERAL FLUMINENSE - IFF. Histórico. 2012. Disponível em: http://portal1.iff.edu.br/nossos-campi/bom-jesus-do-itabapoana/apresentacao. Acesso em: 14 maio 2019.

[8] Portal do Instituto Federal Fluminense. 2016. Disponível em: http://portal1.iff.edu.br/nossoscampi/bom-jesus-doitabapoana/arquivos/2016/abril/regulamentacao-didatico-pedagogicavigente.pdf. Acesso em: 22 de nov. 2018.

[9] KUENZER, A. Z. Ensino Médio: construindo uma proposta para os que vivem do trabalho. São Paulo: Cortez, 2000. 
[10] LOUSADA, A. C. Z.; MARTINS, G. A. Egressos como fonte de informação à gestão dos cursos de Ciências Contábeis. Revista Contabilidade \& Finanças, São Paulo, v. 16, n. 37, p. 73-84, jan./abr. 2005.

[11] MACHADO, L. R. S. Trabalho e educação profissional no Brasil: formação humana ou para o mercado? In: ANAIS DO IX SEMINÁRIO NACIONAL DE ESTUDOS E PESQUISAS, JoãoPessoa: UFPB, 2012. Disponível em 22 de nov. http://www.histedbr.fe.unicamp.br/acer_histedbr/seminario/seminario9/PDFs/7.14.pdf

[12] MARON, N. M. W.; GERMANO, M. S. Perspectivas e desafios para a formação profissional no atual contexto da educação e do mundo do trabalho no Brasil, Trabalho \& Educação, Belo Horizonte, v. 19, n. 2, p. 51-63, mai./ago. 2010.

[13] RAMOS, M. N. A pedagogia das competências: autonomia ou adaptação? São Paulo: Cortez, 2006.

[14] SANCHES, M. C. Políticas públicas: regulamentação do ensino técnico profissional na era Vargas (1930-1945). 2012. 39f. Monografia (Graduação em Pedagogia) - Universidade Estadual de Maringá, Paraná, 2012.

[15] YIN, R. K. Estudo de caso: planejamento e métodos. 5. ed. Porto Alegre: Bookman, 2015.

*Corresponding author.

E-mail address: ludmatta@y ahoo.com.br 